\title{
HABERMAS LEITOR DE WEBER E A ECONOMIA NEOCLÁSSICÁ
}

\author{
FERNANDO HADDAD
}

\begin{abstract}
Este artigo compõe-se de duas partes. A primeira destina-se à apresentação da leitura de Habermas da obra de Max Weber, exposta na sua Teoria do agir comunicativo. Como se sabe, no percurso de construção da sua própria teoria, Habermas percebe uma inconsistência na teoria da racionalização de Weber, que abre caminho para a sua proposta de mudança de paradigma inspirada em Durkheim e G. H. Mead. Não obstante, o que se pretende na segunda parte deste artigo é justamente rejeitar a hipotese de inconsistência da teoria de Weber a partir do estudo da influência da revolução marginalista no pensamento desse autor.
\end{abstract}

\section{WEBER SEGUNDO HABERMAS}

No final do século XIX a situação das ciências sociais era a seguinte: o historicismo (Dilthey) e o neokantismo (Rickert e Wildelband) desafiavam os pressupostos e premissas da filosofia da historia (Condorcet) e do evolucionismo (Spencer). Max Weber fez coro contra esses pressupostos e premissas, mas o caráter inovador da sua posição reside no fato de que, apesar disso, ele não renuncia ao projeto de entender a modernização como resultado de um processo histórico-universal de racionalização.

No Esquisse d'un Tableau Historique des Progrès de l'Esprit Humain (1794) Condorcet apresenta os motivos mais importantes da moderna filosofia da história. Assim como Kant, Condorcet se vê impressionado com a evolução das ciências matemáticas da natureza, especialmente a Física de Newton. Mas se Kant, na Crítica da Razão Pura, procura esclarecer os fundamentos do conhecimento e com isso as condições de racionalidade da ciência, Condorcet se interessa pelas conseqüências do 
inevitável crescimento do saber teórico sobre o desenvolvimento do espírito humano e da cultura.

Habermas resume as considerações de Condorcet aos seguintes pontos. Condorcet rompe com a idéia aristotélica de perfeição, entendida como a realização de um telos inscrito na própria natureza da coisa, e passa a interpretá-la como mero progresso, isto é, como um aperfeiçoamento que não está pré-determinado. Assim, os progressos do espírito humano devem-se a um mecanismo de aprendizagem não limitados por um telos imanente. Os limites ao progresso, agora, Condorcet vai encontrá-los nas figuras do preconceito e da superstição. Daí os outros traços característicos do seu pensamento: o progresso das ciências da natureza pode se converter em racionalização da vida social se os cientistas assumirem a tarefa da educação pública. E, como para Condorcet não há erros, políticos e morais, não fundados, em última instância, na incompreensão das leis físicas da natureza, poder-se-ia esperar, juntamente com o progresso das ciências da natureza, um progresso igualmente vigoroso das ciências normativas.

Habermas identifica quatro pressuposições subjacentes a esse tipo de pensamento que viriam a se tornar problemáticas com o curso do tempo e sobre as quais Weber tomaria posição. Em primeiro lugar, tem-se a idéia de que todos os problemas propostos pela religião e pela filosofia poderiam ou ser convertidos em problemas científicos passíveis de solução racional ou ser denunciados como falsos problemas, o que os faria desaparecer objetivamente. Contra isso, insurge-se o historicismo, destacando a peculiaridade do âmbito cultural que, apesar dos nexos de sentido, não obedece a uma legalidade nomológica ou natural-evolucionista. Weber leva a sério a crítica historicista, recolocando o problema da racionalização sem se utilizar da evolução das ciências da natureza como fio condutor, mas valendo-se da evolução das imagens religiosas do mundo: "As mutações orientadas capazes de induzir processos cumulativos tinham que se fazer derivar da lógica interna dos nexos de sentido, das idéias, e não de mecanismos evolutivos dos sistemas sociais; tinham que explicar-se em termos estruturalistas e não em virtude de leis da evolução social" (Habermas, 1989: 210).

Em segundo lugar, a filosofia da história pressupõe a unidade da razão teórica e da razão prática. Contra todas as variantes de naturalismo ético insurge-se o neokantismo, fazendo valer a distinção metodológica entre ser e dever. Weber também se manifesta contra a confusão entre enunciados descritivos e avaliativos, mas, paradoxalmente, associará a essa posição uma desconfiança antikantiana e historicista contra a capacidade argumentativa da razão prática. 
Em terceiro lugar, a filosofia da história carrega consigo uma pretensão universalista. A racionalidade das ciências da natureza não reflete os padrões da civilização do Ocidente, mas é inerente ao espírito humano em geral. Contra isso o historicismo enfatizou a relatividade das tradições e formas de pensamento, inclusive dos padrões de racionalidade das ciências empíricas. "Nesta controvérsia, Max Weber adotou, como ainda veremos, uma cautelosa posição universalista. Não considerou os processos de racionalização como um fenômeno particular do Ocidente, se bem que os fenômenos de racionalização, que se podem identificar em todas as religiões mundiais, só na Europa conduziram a uma forma de racionalismo que oferece simultaneamente traços particulares, quer dizer, ocidentais, e traços gerais, quer dizer, traços que distinguem a modernidade como tal" (idem: 212).

Por fim, a filosofia da história de Condorcet pressupõe uma "eficácia automática do espírito". A redução dos progressos da civilização a progressos do espírito exige que a acumulação do saber se torne empiricamente eficaz, automaticamente. As experiências históricas centrais do século XIX, entretanto, punham em cheque esse pressuposto. Com a Revolução Industrial tornou-se clara a importância das técnicas de produção, cujo desenvolvimento não se deveu, em sua origem, à tradução do progresso científico, para explicar o crescimento econômico e a organização racional da sociedade. Por outro lado, os processos de institucionalização das liberdades civis pareciam muito mais o resultado das convulsões políticas iniciadas com a Revolução Francesa do que o resultado de um progresso das ciências humanas. Finalmente, o desenvolvimento da economia capitalista como subsistema funcionalmente autônomo permitia considerá-lo, por analogia com os organismos vivos, como um sistema que se conserva a si mesmo. "Os primeiros motivos, ensina Habermas, favoreceram uma releitura empirista dos processos de racionalização como processos de crescimento, enquanto o terceiro facilitou a assimilação da história das sociedades ao modelo evolutivo que Darwin havia introduzido para a filosofia da natureza. Assim, pôde Spencer propor uma teoria da evolução social que acabou com o confuso idealismo da filosofia da história, que considerava os progressos da civilização como continuação da evolução natural e que com isso os subsumia, já sem equivocidade alguma, sob leis naturais" (idem: 208). Não obstante a revisão que o evolucionismo spenceriano procede da visão do processo de racionalização proposto pela filosofia da história, ambos compartilham a idéia de que ora a ciência ora a técnica apresentam-se como mecanismo resolutórios de problemas. Na trilha da crítica burguesa da cultura, porém, Weber, influenciado por Nietzsche e pelo vi- 
talismo contemporâneo, vê-se comprometido com uma visão pessimista da sociedade cientificizada. "Desconfia dos processos de racionalização abandonados à sua própria lógica, isentos de toda orientação éticovalorativa" (idem: 212).

A partir desses quatro aspectos mencionados, Weber recoloca a questão do nascimento e desenvolvimento das sociedades modernas como processo de racionalização. Antes de esclarecer o conceito de racionalidade utilizado por Weber, Habermas procura apresentar aquilo que para ele são os sintomas desse processo nos três núcleos estruturais do mundo da vida. No plano da sociedade, Weber entende a racionalização como o processo de emergência: 1) da empresa capitalista separada do âmbito doméstico, que, com a ajuda do cálculo contábil e da utilização técnica do conhecimento científico, organiza a força de trabalho com o máximo de eficiência, pautando seus investimentos pelas oportunidades oferecidas pelo mercado; e 2) do Estado moderno, organizado sobre a base de um controle centralizado que, dispondo de um poder militar permanente, monopoliza a criação do direito e o emprego legítimo da força e exerce burocraticamente a dominação através de um corpo de funcionários especializados. No plano da cultura, Weber entende a racionalização como o processo de diferenciação de três esferas autônomas de valor, a cognitiva, a expressiva e a prático-moral, cada qual obedecendo à sua própria lógica. Do ponto de vida cognitivo, Weber privilegia o fenômeno da recepção da ciência pela economia, que, segundo ele, teria contribuído para o desenvolvimento da metodização da vida. Do ponto de vista expressivo, Weber atenta para as consequiências da arte autônoma sobre as técnicas de produção artística (harmonia, notação e construção de instrumentos) e para o surgimento de uma subjetividade emancipada das convenções cognitivas e prático-morais, que "cultiva experiências no trato com a própria natureza interna". Do ponto de vista prático-moral, Weber vai mostrar como a autonomização do direito e da moral, que conduz ao direito formal positivo e às éticas da intenção e da responsabilidade, prosperou graças à radicalização das profecias de redenção que, partindo da religiosidade interior, prenunciam os rudimentos de uma ética da intenção universalista e regida por princípios, ao superar a separação entre moral interna e moral externa, a partir de uma preocupação fraternal com o próximo. "Da perspectiva de uma ética formal baseada em princípios universais ficam desvalorizadas as normas jurídicas (...) que apelem à magia, às tradições sagradas, à revelação etc.: as normas se consideram simples convenções suscetíveis de serem ajuizadas em atitude hipotética, que podem estabelecer-se de forma positiva" (idem: 220). No plano da personalidade, Weber entende a racionalização como o processo de metodização da vida a partir daqueles 
fundamentos motivacionais que orientam o comportamento dos membros das seitas protestantes, caracterizado por uma recusa dos meios mágicos, pelo cumprimento dos deveres profissionais, pela transformação da recusa judaico-cristã do mundo em ascese intramundana e pela crença na necessidade de cada indivíduo assegurar-se da própria salvação.

Dados os sintomas do processo de racionalização, Habermas passa a explorar a racionalidade, tal como vista por Weber, agora do ponto de vista conceitual. Segundo Habermas, Weber diferencia "o conceito de racionalidade prática [aquela na qual Weber está primordialmente interessadoFH] sob o triplo aspecto da utilização de meios, da eleição de fins e da orientação de valores. A racionalidade instrumental de uma ação se mede pela eficácia no planejamento do emprego de meios para fins dados; a racionalidade eletiva de uma ação se mede pela correção do cálculo dos fins para valores articulados com precisão e para meios e condições de contorno dados; e a racionalidade normativa de uma ação se mede pela força sistematizadora e unificante e pela capacidade de penetração que têm os padrões de valores e os princípios que subjazem às preferências de ação. Às ações que cumprem as condições dos meios e da racionalidade eletiva Weber chama 'racionais regidas por fins' e às ações que cumprem as condições de racionalidade normativa, 'racionais regidas por valores"' (idem: 233). Se, contudo, o conflito entre fins concorrentes for dirimido em atenção a quaisquer ordens de valores, e não através da redução desses fins a desejos subjetivamente hierarquizados, temos uma ação racional regida por fins só nos meios.

Aqui, é imperativo distinguir entre a racionalidade de uma ação regida por valores e a racionalidade dos próprios postulados de valor. Um cético em questões normativas como Weber não poderia justificar uma decisão entre distintos sistemas de valores. Não obstante, segundo Weber, a racionalidade dos valores pode ser mensurada, se não pelo seu conteúdo material, pelas suas propriedades formais. Só os valores transformados em princípios têm uma força orientadora capaz de reger uma forma de vida. Daí a possibilidade de uma pessoa racional poder guiar-se por valores, isto é, segundo suas conviç̧ões sobre o dever, a dignidade, os preceitos religiosos, etc. Nesse sentido, Weber reafirma a distinção tão cara ao neokantismo entre interesse e valor contra a visão utilitarista, que não faz mais do que tentar converter os interesses em princípios éticos e hipostasiar a racionalidade regida por fins, convertendo-a em um valor. Essa distinção permite a Weber explicar, a partir da relativa autonomia entre a racionalidade regida por fins frente à regida por valores, a possibilidade de progresso na dimensão de uma dessas racionalidades em detrimento da outra (cultura ocidental, num pólo, vs. budismo primitivo, no outro). 
Vale notar que, nesse ponto da argumentação, torna-se clara a conexão entre racionalização das ações e racionalização das imagens do mundo. Pois, se os sistemas de valores podem ser considerados mais racionalizados em função do grau de elaboração e configuração formais do sistema de símbolos, Weber terá que valorizar aquela camada de intelectuais responsável pela racionalização dogmática das religiões de redenção, remetendo, desta forma, a um conceito de racionalidade que compreende tanto a racionalidade prática como a teórica, racionalidade esta que não está diretamente projetada em termos de teoria da ação.

Essa tarefa de formalização, levada a cabo pelo trabalho analítico dos intelectuais, Weber a toma em dois aspectos distintos. Por um lado, as imagens racionalizadas do mundo satisfazem as exigências do pensamento operacional-formal. Por outro, satisfazem as exigências de compreensão moderna do mundo. Na sua interpretação de Weber, Habermas distingue a simples "sistematização dos conteúdos de fé" por meio da ampliação do âmbito de aplicação de operações intelectuais formais da "redução a princípios", que acarreta uma descentralização das perspectivas sob as quais se apreende o mundo. A primeira é uma condição necessária, mas de forma nenhuma suficiente para a passagem a uma concepção moderna do mundo. Só com a diferenciação das esferas de valor se pode falar de uma compreensão moderna do mundo e, portanto, de uma racionalização cultural em sentido estrito. Tal movimento só ocorreu no Ocidente. A partir daí, a questão central para Weber só pode ser a seguinte: que encadeamento de circunstâncias conduziram a que precisamente aí se produzisse esse fenômeno cultural que veio a ter significação e validade universais?

Antes de explicar o papel que terá a ética protestante no quadro da sociologia weberiana é necessário explicitar a lógica de racionalização das imagens do mundo. Weber parte da idéia de que os homens, na condição de seres de cultura, têm, por um lado, interesses materiais por bens terrenos como saúde, bem-estar, longevidade, etc., e, por outro, interesses ideais por bens soteriológicos como graça, redenção, vida eterna, etc. Mas as ordens de vida social não são só vistas sob o aspecto da satisfação de interesses materiais e ideais, mas também sob o aspecto da realização de idéias ou valores. Os interesșes só são satisfeitos aliando-se a idéias que os justifiquem e legitimem e "as idéias só se podem impor empiricamente aliando-se com interesses que as dotem de força". Com exceção dos casos em que uma ordem de vida social se baseia na intimidação e no terror, no caso normal ela goza de um reconhecimento subjetivamente vinculante e obrigatório, apoiado num corpo de idéias (e não só na trama de interesses) que a fundamenta. Contudo, é por meio dos interesses com que se integram que as idéias ganham eficácia fática e se materializam, de uma forma 
incompleta, é verdade, numa ordem legítima. Dessa incompletude, aliás, deriva o fato de que, apesar de seu caráter consensual, a ordem se mantém e se estabiliza graças a um sistema de sanções externas e internas.

Neste quadro, ganha revelo a questão crucial de como, num mundo em que o válido é o regular, é possível uma inovação. "Não há dúvida, ensina Weber, que, visto de fora, [a inovação nasce] mediante uma mudança das condições externas de vida. Mas, estas [mudanças externas] não dão a menor garantia de que a resposta não seja uma decadência da vida em lugar de uma nova ordem; e, sobretudo, não constituem de modo algum a condição indispensável; em muitos casos de novas ordens de grande alcance não é sequer uma condição cooperante. Senão que, segundo todas as experiências da etnologia, a fonte mais importante da nova ordem parece ser a influência dos indivíduos que, em virtude de vivências 'anormais' (...) são capazes de influir sobre os demais" (Weber, 1992: 260; cfr. Habermas, 1989: 257).

Partindo dessas considerações, a relação entre idéias e interesses pode agora ser mais bem visualizada naquela passagem da introdução aos Ensaios de sociologia da religião onde Weber, implicitamente, replica o argumento central do famoso Prefácio... de Marx: "São os interesses, materiais e ideais, não as idéias, que dominam imediatamente a ação dos homens. Mas as 'imagens do mundo' criadas pelas 'idéias' têm determinado, com grande frequiência, como bússolas, as vias nas quais a ação se vê empurrada pela dinâmica dos interesses" (Weber, 1984: 247; cfr. Habermas, 1989: 257).

A relação entre idéias e interesses que, no plano da sociedade, explica o aparecimento de ordens legítimas e âmbitos de existência institucionalmente ordenados, aparece também no plano da cultura para explicar a evolução da própria imagem de mundo. Habermas, partindo das observações de $R$. Döbert, traça uma importante distinção metodológica entre aspectos estruturais e aspectos de conteúdo para compreender a evolução das imagens religiosas-metafísicas do mundo. Enquanto estes refletem as distintas soluções dadas ao problema da justiça divina, aqueles se referem às distintas posturas frente ao mundo, determinadas por conceitos formais de mundo. Sendo assim, a direção do desenvolvimento religioso se pode explicar pela lógica interna das estruturas de todas as imagens de mundo. Com efeito, as investigações de Weber confirmam que todas as religiões partem do mesmo problema da teodicéia e apontam na mesma direção de uma visão desencantada do mundo, depurada de representações mágicas. Já "os conteúdos específicos em que se traduzem as possibilidades circunscritas por essas estruturas é mister fazê-los derivar de fatores externos". Assim, segundo Habermas, "Weber entende a racionalização das 
imagens do mundo como um processo que aponta na mesma direção em todas as religiões universais; [mas] que por razões externas só é levado radicalmente até o final em uma dessas linhas de tradição, de modo que só no Ocidente libera esse processo as estruturas de consciência que possibilitam a compreensão moderna do mundo" (Habermas, 1989: 264).

Weber mede o grau de racionalização de uma religião pela distância que ela toma do pensamento mágico. Pois o que é comum a todas as religiões, segundo Weber, é a tentativa de explicar a distribuição desigual de bens materiais e soteriológicos entre os homens. E a colocação da questão nesses termos já contém um traço de ruptura com o pensamento mágico, principalmente no que concerne à idéia de sofrimento. Para a magia, o sofredor incorre na ira de um deus ou experimenta a possessão de um demônio. Diferentemente, a religião busca uma explicação para o sofrimento, percebido como injusto. Por trás disso, encontra-se a concepção de que o mundo em sua totalidade é ou pode ser um cosmos com sentido, concepção que amalgama aspectos ônticos e normativos. Além disso, se a magia está primordialmente interessada na superação das situações de penúria coletiva, a religião se ocupa da salvação do indivíduo, ou seja, do sofrimento encarado do ponto de vista individual.

Partindo desse mesmo problema fundamental, as religiões, no que concerne aos aspectos de conteúdo, serão distinguidas por Weber segundo duas dimensões: a idéia de Deus e a orientação soteriológica. $\mathrm{Na}$ primeira dimensão, Weber contrasta a concepção ocidental de um Deus criador, supramundano e pessoal (teocêntrica) e a concepção oriental (imanentista de Deus) de um cosmos impessoal e incriado (cosmocêntrica). "O 'Deus da ação' está exemplarmente desenvolvido em Jeová; o 'Deus da ordem', em Brahma. Frente ao Deus criador e transcendente, o crente tem que adotar uma relação muito distinta que frente ao quieto fundamento da ordem cósmica; se entende a si mesmo como instrumento de Deus e não como recipiente do divino. No primeiro caso, o crente busca o beneplácito de Deus; no outro, participar do divino. Também se distingue em ambas tradições o fundamento religioso da ética: à esperança na graça se opõe na religiosidade asiática a idéia da autoredenção pelo saber" (Habermas, 1989: 269). Na segunda dimensão, Weber contrasta a concepção de um mundo natural e social com valor intrínseco (afirmação do mundo), e a concepção de um mundo que aparece aos olhos do crente como "uma simples fachada fenomênica frente ao fundo essencial de todas as coisas" (negação do mundo).

Exclusivamente quanto aos conteúdos, portanto, podemos ter uma afirmação cosmocêntrica do mundo (confucionismo e taoísmo), uma negação cosmocêntrica do mundo (budismo e hinduísmo) e uma negação 
teocêntrica do mundo (judaísmo e cristianismo). Weber explica essas diferenças de conteúdo, recorrendo a fatores externos tais como a origem social das camadas responsáveis pela metodização da vida, pelas características psicológicas dessas mesmas camadas, pelos conflitos sociais que se travam no momento da revelação profética, etc. Mas Weber não se esquece de alertar: "certamente, o modo de vida das camadas sociais decisivas costumam ter uma influência profunda em toda religião, mas também, por outra parte, o tipo de religião, uma vez cunhado, costuma exercer uma influência muito intensa no modo de vida de camadas muito heterogêneas" (Weber, 1984: 236).

Quanto aos aspectos estruturais, Habermas, na sua apresentação da teoria weberiana, adota uma perspectiva muito atraente: descreve as posturas frente ao mundo que Weber distingue, analisando os distintos caminhos de salvação. Mas, motivado pelos estudos de J. Needham, referese não só ao processo de etização das imagens do mundo, mas também à transformação dos seus componentes cognitivos. Segundo Habermas, radica aí uma das limitações da teoria weberiana, qual seja, não ter estudado o processo de racionalização das imagens do mundo sob os pontos de vista cognitivo e expressivo.

Weber, em primeiro lugar, afirma que as religiões de redenção que negam o mundo, caracterizadas principalmente por um mais contrastante dualismo entre Deus e o mundo, cumprem melhor as condições de racionalização ética, uma vez que conduzem para a busca de bens de salvação interiores como meio de redenção. Mas, evidentemente, a busca de um bem soteriológico transcendente ao mundo só favorece uma racionalização ética do modo de vida se for acompanhada de uma orientação de vida voltada para o domínio do mundo. É assim que Weber, em segundo lugar, distingue as posturas de negação conforme o crente se veja como instrumento de Deus ou como recipiente do divino, ou, em outras palavras, conforme o crente busque a redenção através de uma ascética ativa (judaísmo e cristianismo) ou através de uma fuga do mundo (hinduísmo). Não custa lembrar que "a atitude de dominação ascética do mundo, que o monge cristão compartilha com o puritano, [ainda] não significa todavia a extensão do comportamento eticamente racionalizado aos âmbitos extrareligiosos" (Habermas, 1989: 276).

Quanto à postura de afirmação do mundo, Weber a analisa sob uma única forma: a de acomodação ao mundo. $\mathrm{E}$, tomando-a sob o ponto de vista exclusivo da racionalização ética, Weber, segundo Habermas, negligencia aqueles aspectos, sublinhados por Needham, sobre o desenvolvimento do saber teórico e a aplicação deste saber para necessidades práticas, que colocam, no plano cognitivo, a China confucionista, do sécu- 
lo I a.C. até o século XV d.C., muito à frente do mundo ocidental. Na opinião de Habermas, Weber deveria, num caso como o chinês, ter investigado o potencial de racionalidade sob o ponto de vista cognitivo. Esse procedimento se justificaria, ademais, pelo fato de que também a filosofia grega compartilha com a ética chinesa a postura de afirmação do mundo, tendo se chocado, tanto quanto a ciência chinesa, com os mesmos limites, de raiz ética, de uma atitude não intervencionista frente à natureza e à sociedade. Não obstante, a postura chinesa frente ao mundo difere da grega pelo fato de que quando prevalecem, como na China, as necessidades práticas, "a atitude fundamental de afirmação do mundo toma a forma de uma acomodação ao mundo. A afirmação do mundo só parece conduzir a uma objetivação do mundo sob aspectos puramente teóricos quando se une com uma forma de vida teorética exonerada de preocupações práticas e se põe à serviço do theorein. A camada culta chinesa não pôde apoiar-se, como a grega, em uma vida apartada do prático e dedicada à contemplação, em uma vida 'acadêmica', em um bios theoretikos" (Habermas, 1989: 278).

Veja-se que a distinção entre afirmar ou negar o mundo não implica, per se, nenhuma atitude ativa ou passiva frente à vida, uma vez que se pode afirmar o mundo ativa e passivamente (acomodação e contemplação, respectivamente), bem como negar o mundo ativa ou passivamente (dominação e fuga, respectivamente). Neste ponto, Habermas levanta uma hipótese estimulante: a de que quando se unem uma postura teocêntrica com uma postura de contemplação do mundo, ou seja, uma forma ativa de busca de salvação com uma forma passiva de assegurar-se no mundo, pode-se, como ocorreu no Ocidente, levar mais longe a objetivação do mundo sob os aspectos ôntico e ético.

Efetivamente, essas duas imagens do mundo, a religião cristã e a filosofia grega, que contam com um potencial de racionalização mais alto, entram em contato dentro da mesma tradição européia. "Isto gera a produtiva tensão que caracteriza a história cultural medieval européia. O choque conduz a uma polarização, isto é, a uma radical elaboração das categorias específicas de cada imagem do mundo, quer dizer, das categorias de uma ética religiosa da intenção, de um lado, e de uma cosmologia de base teórica, de outro. Simultaneamente, esse choque obriga também à síntese dos conceitos formais de mundo, formados, respectivamente, sob aspectos éticos ou sob aspectos ontológicos" (Habermas, 1989: 282). Segundo Habermas, se Weber tivesse tido tempo de concluir seus estudos comparativos das religiōes universais, que incluía o cristianismo e o islamismo, teria percebido a importância da racionalização das estruturas cognitivas que acompanha a racionalização das imagens de mundo. "Daí, conclui Habermas, 
que tampouco fique suficientemente claro que entre os resultados da racionalização das imagens do mundo e a compreensão do mundo especificamente 'moderna', todavia, medeia mais um passo" (ibidem).

A unidade da imagens do mundo racionalizadas está baseada em princípios supremos (Deus, ente, natureza, etc.), que fundam, por assim dizer, toda a argumentação. Não obstante, esses princípios, eles próprios, não são expostos a uma crítica argumentativa. Neles encontramse fusionados os aspectos descritivos, normativos e expressivos cuja dinâmica opera, sem independência, por dentro das imagens de mundo. Nas imagens racionalizadas encontra-se ainda um fragmento de pensamento mítico. O passo decisivo na direção de uma compreensão moderna do mundo, que não conhece limites à força crítica do pensamento hipotético, exige a "aplicação conseqüente da forma de pensamento conseguida por racionalização ética e cognitiva aos âmbitos profanos da vida e da experiência" (idem: 283), o que só se tornou possível quando, de um lado, (fenômeno ao qual Weber presta menos atenção) superou-se, por meio da ciência moderna, a separação da vida teórico-contemplativa com relação aos âmbitos experienciais da prática e do trabalho social, e, de outro lado, anularam-se, por meio da ética protestante da profissão, a ruptura entre busca ascética de salvação e as ordens profanas do mundo.

Na sociologia de Max Weber, só esse segundo fenômeno joga o papel chave. O calvinismo, particularmente, não só difundiu a atitude ascética intramundana, como também promoveu um modo de vida sistematizado em torno do exercício racional da profissão: o êxito na atividade profissional passa a ser visto como um sinal que permite ao crente assegurarse de seu estado de graça. Descarta, ademais, a oscilação católica entre pecado, arrependimento, penitência, desencargo de consciência e volta a pecar: a vida se despoja de seu caráter assistemático e se converte em um método que envolve toda a existência. A moral se vê agora paradoxalmente ancorada no exercício racional regido por fins da profissão, ou seja, numa esfera emancipada da eticidade tradicional. Curiosamente, a ética cristã da fraternidade, entendida por Weber como modelo de uma ética da intenção racionalizada baseada em princípios universalistas, que exerceu um papel fundamental na racionalização das imagens de mundo ocidentais, entra em choque com as ordens intramundanas racionalizadas. No seu lugar, a ética protestante renuncia ao universalismo do amor e objetiviza racionalmente toda intervenção no mundo como um serviço a Deus e querido por Deus, abandonando a perspectiva fraterna de uma redenção acessível a todos pela concepção não fraterna de uma graça arbitrária e particular.

Essa ética, não obstante, não teve melhor sorte. "A ética protes- 
tante satisfaz as condições necessárias para o nascimento de uma base motivacional da ação racional regida por fins na esfera do trabalho social. Mas com essa ancoragem 'racional regida por valores' das orientações de ação racionais regidas por fins , essa ética so satisfaz as condições de partida da sociedade capitalista; a ética protestante põe em marcha o capitalismo, mas sem poder garantir as condições de sua própria estabilidade como ética" (idem: 299). Weber investiga, então, como se torna operante o potencial cognitivo surgido da racionalização das imagens de mundo, centrando suas preocupações no processo de institucionalização da ação racional regida por fins e vai se ocupar, quase que exclusivamente, daqueles complexos institucionais em que vê objetivizadas as estruturas de consciência modernas: a economia capitalista e o Estado moderno.

Weber crê que esses complexos institucionais, cuja condição de existência depende da separação do trabalhador dos meios de trabalho (seja dos meios de produção, na economia, seja dos meios materiais, na administração pública, seja dos meios bélicos, no exército), concentrando os meios de trabalho em mãos de empresários ou dirigentes obrigados ao cálculo racional, constituem um ambiente destrutivo para a ética protestante, na medida em que se desenvolvem segundo a legalidade cognitivoinstrumental típica da empresa capitalista e do Estado moderno. Dessa forma, "a racionalidade prático-moral da ética da intenção não pode institucionalizar-se na sociedade cujo início ela faz possível. Com o tempo, fica substituída por um utilitarismo que é fruto de uma reinterpretação empirista da moral, quer dizer, de uma reavaliação pseudomoral da racionalidade regida por fins, e que já não dispõe de uma relação interna com a esfera do valor moral" (idem: 299/300).

Para Habermas, não obstante, Weber fica por provar a impossibilidade de que uma ética regida por princípios possa sobreviver em contextos outros que não os religiosos. Com efeito, os estudos de B. Groethuysen concentram-se justamente sobre a formação, na burguesia francesa, de uma consciência moral civil autônoma frente a Igreja, sugerindo a possibilidade de uma ética regida por princípios dissociada da religião. E, além dessa evidência empírica, Habermas apresenta um argumento sistemático que tem um peso significativo na construção da sua teoria: "se a etização das imagens religiosas do mundo conduz à diferenciação de uma esfera de valor especializada em questões prático-morais, cabe esperar que a racionalização ética prossiga dentro desta esfera, atendo-se daí em diante à legalidade própria de uma razão prática emancipada de pretensões descritivas e expressivas. Nesta linha se movem as 'éticas filosófico-profanas da intenção' do mundo moderno, que através das éticas formalistas de cunho kantiano conduzem às 'éticas do discurso' da atuali- 
dade, as quais conectam em parte com Kant e em parte com o direito natural racional, ainda que recolhendo também motivos utilitaristas. Seguindo Weber, poderíamos chamá-las éticas cognitivistas da responsabilidade" (idem: 302). Não fosse a possibilidade de uma ética de fundamentação não religiosa, o próprio Weber não teria podido assumir o papel de teórico da moral, ao defender a superioridade da ética da responsabilidade frente à ética da intenção.

Salta à vista, nesse particular, o lugar que o direito acaba por ocupar na teoria weberiana. Ignorando a possibilidade de uma ética racional, Weber reinterpreta o direito moderno como meio de organização desprovido de toda substância prático-moral, aparecendo desde o início como a materialização institucional da racionalidade cognitivo-instrumental. Antes, porém, de expor a teoria weberiana da evolução do direito, convém, seguindo Habermas, apresentar o diagnóstico weberiano da atualidade, uma vez que é nesse contexto que se explica a estratégia adotada por Weber concernente ao direito.

Esse diagnóstico baseia-se na concepção crítica de duas tendências já discutidas: no plano da cultura, a diferenciação de esferas autônomas de valor; no plano da sociedade, a crescente independência dos sistemas de ação racional regida por fins. A essas tendências correspondem duas teses da maior importância, a tese da perda de sentido e a tese da perda de liberdade, respectivamente.

Com relação à primeira tese, Weber observa o rompimento da unidade das imagens religiosas-metafísicas do mundo e, conseqüentemente, a impossibilidade de atribuir-lhe um sentido. Os princípios supremos em que se fundavam essa imagens racionalizadas mantinham a unidade dos três aspectos sob os quais o mundo poderia ser acessível. Contudo, com a diferenciação das esferas de valor, cada qual seguindo uma lógica própria de desenvolvimento, "a razão se dissocia, destruindo sua propria universalidade". O que se vê, no seu lugar, é a inevitabilidade de conflitos derivados do fato dessas distintas esferas penetrarem simultaneamente um mesmo âmbito institucional. Weber descreve essa situação como um "novo politeísmo", numa referência ao processo de personificação de conflitos entre valores como um conflito entre deuses projetado nos céus.

Vale a pena a reprodução do texto onde Weber recusa tanto a unificação ética do mundo em nome da fé quanto a unificação teorética do mundo em nome da ciência: "A impossibilidade de alguém se fazer campeão de convicções práticas 'em nome da ciência' - exceto o caso único que se refere à discussão dos meios necessários para atingir fim previamente estabelecido - prende-se a razões muito mais profundas. Tal atitude é, em princípio, absurda, porque as diversas ordens de valores se de- 
frontam no mundo, em luta incessante. Sem pretender traçar o elogio da filosofia do velho Mill, impõe-se, não obstante, reconhecer, que quando se parte da experiência pura, chega-se ao politeísmo. A fórmula reveste-se de aspecto superficial e mesmo paradoxal, mas, apesar disso, encerra uma parcela de verdade. Se há uma coisa que atualmente não mais ignoramos é que uma coisa pode ser santa não apenas sem ser bela, mas porque e na medida em que não é bela - e a isso há referências no capítulo LIII do Livro de Isaías e no salmo 21. Semelhantemente, uma coisa pode ser bela não apenas sem ser boa. Nietzsche relembrou esse ponto, mas Baudelaire já o havia dito por meio das Fleurs du Mal, título que escolheu para sua obra poética. A sabedoria popular nos ensina, enfim, que uma coisa pode ser verdadeira, conquanto não seja bela nem santa nem boa. Esses, porém, não passam dos casos mais elementares da luta que opõe os deuses das diferentes ordens e dos diferentes valores. Ignoro como se poderia encontrar base para decidir 'cientificamente' o problema do valor da cultura francesa face à cultura alemã; aí, também, diferentes deuses se combatem e, sem dúvida, por todo o sempre. Tudo se passa, portanto, exatamente como se passava no mundo antigo, que se encontrava sob o encanto dos deuses e demônios, mas assume sentido diverso. Os gregos ofereciam sacrifícios a Afrodite, depois a Apolo e, sobretudo, a cada qual dos deuses da cidade; nós continuamos a proceder de maneira semelhante, embora nosso comportamento haja rompido o encanto e se haja despojado do mito que ainda vive em nós" (Weber, 1993: 41; apud Habermas, 1989: 320). Essa passagem "completa" a "dialética do esclarecimento" ocidental, a partir da qual Weber interpreta o desafio existencial de nosso tempo. Os poderes pessoais do antigo politeísmo, destronado pelo racionalismo, retornam na forma de poderes impessoais desencantados, depois de o pathos da ética cristã ter mascarado, por mil anos, os eternos conflitos entre valores que envolvem nossas vidas. Aos que anseiam por novos profetas e salvadores, Weber recomenda um outro caminho que consiste em "entregar-se ao trabalho e responder às exigências de cada dia", tarefa que se torna fácil "se cada qual encontrar e obedecer ao demônio que tece as teias de sua vida".

Com relação à segunda tese, Weber investiga a ameaça à liberdade do indivíduo representada pela crescente autonomia da empresa capitalista e do Estado moderno. Permito-me, aqui também, reproduzir o texto em que Weber a formula: "(...) um dos elementos constitutivos do moderno espírito capitalista (e não somente deste, senão de toda cultura moderna), a saber, a condução racional da vida sobre a base da idéia de profissão, teve sua origem no capitalismo da ascese cristã. (...). Pois ao transferir-se a ascese das celas monacais à vida profissional e começar seu 
domínio sobre a moral intramundana, contribuiu para a construção deste poderoso cosmos da ordem econômica moderna que, ligado às condições técnicas e econômicas da produção mecânico-maquinista, determina hoje, com força irresistível, o estilo de vida de todos os que nascem dentro de suas engrenagens (não so dos que participam diretamente na atividade econômica), e lhe seguirá determinando quiçá até que acabe por consumir a última tonelada de combustível fóssil. A preocupação pelos bens exteriores, dizia Baxter [ministro puritano que influenciou o protestantismo inglês do século XVII - FH], só devia pesar sobre o ombro de seus santos como 'um leve manto do qual se pode despojar a qualquer instante'. $O$ destino converteu esse leve manto em um invólucro férreo. $\mathrm{O}$ ascetismo se propôs a tarefa de atuar no mundo e transformá-lo; com isso, os bens exteriores deste mundo alcançaram um poder crescente e ao fim irresistível sobre os homens, um poder que não houve semelhante na história. Hoje seu espírito deslizou para fora desse invólucro, quem sabe se definitivamente. O capitalismo vitorioso, descansando como descansa em um fundamento mecânico, já não necessita, em todo caso, de seu apoio. (...). Ninguém sabe, todavia, quem habitará no futuro este invólucro vazio, ninguém sabe se ao fim desse prodigioso desenvolvimento surgirão novos profetas ou renascerão com força antigas crenças e ideais, ou se, à falta disso, não se perpetuará a petrificação mecanizada guarnecida de um tipo de convulsivo sentir-se importante. Neste caso, os 'últimos homens' desta cultura farão verdade aquela frase: 'especialistas sem espírito, hedonistas sem coração, essas nulidades se imaginam ter alcançado um estágio da humanidade superior a todos os anteriores'" (Weber, 1984: 198/200; apud Habermas, 1989: 322).

Habermas submete essas duas teses a um exame crítico. Quanto à tese da perda de sentido, acusa Weber de ter inferido a incompatibilidade de distintas formas de pretensões de validade a partir da perda de unidade substancial da razão, sem se dar conta de que essa unidade pode ser assegurada, no plano formal, pelo desempenho argumentativo comum a essas pretensões. Segundo Habermas, o pluralismo irreconciliável advogado por Weber existe sim, mas entre sistemas de valores no que concerne seu conteúdo. Daí não se poder reduzir, por exemplo, a cultura francesa à alemã. Isso, porém, nada tem a ver com os aspectos de validade sob os quais se diferenciam as esferas culturais de valor. Assim, Weber não teria distinguido com suficiente clareza os conteúdos particulares de valor e os critérios universais de valor.

Essa confusão entre conteúdos particulares e critérios universais contamina, segundo Habermas, a análise weberiana do processo de racionalização do direito. E aqui esbarramos em aspectos da tese da perda de li- 
berdade. Pois que a racionalização do direito só é compatível com essa tese se puder ser abordada sob o prisma exclusivo da racionalidade formal, isto é, desprovida de valor. É a opção de Weber. Pois, caso tivesse realçado as analogias entre evolução moral e racionalização jurídica, o que, para Habermas, considerando-se a própria abordagem de Weber seria o natural, ele teria obrigatoriamente que relaxar a hipótese do invólucro férreo que submete os indivíduos. Não o fazendo, Weber involuntariamente substitui o modelo das três esferas de valor racionalizadas segundo sua própria lógica por um modelo de pluralidade de valores soltos (direito, poder, riqueza, verdade, beleza, etc.) racionalizáveis sob o aspecto único das relações meio-fim (a ciência do direito, nessa perspectiva, restringe-se a indicar a regra jurídica mais adequada para obter determinado fim, de acordo com as normas do pensamento jurídico, sem questionar-lhe a justiça ou a própria existência).

Essas contradições, segundo Habermas, derivam de uma contradição central: "Por um lado (...) Weber dispõe de um conceito complexo de racionalidade prática, que parte de uma coordenação dos aspectos 'racionais regidos por fins' e 'racionais regidos por valores' da ação. Mas, por outro lado, Weber considera a racionalização social exclusivamente sob o aspecto da racionalidade regida por fins. Esse conceito compreensivo de racionalidade que Weber põe à base de suas investigações sobre a tradição cultural não o aplica ao plano das instituições" (Habermas, 1989: 329). São essas tendências contraditórias que vão se refletir na sua sociologia do direito, visto como uma ordem que obedece ora a formas de racionalidade prático-moral ora a formas de racionalidade cognitivoinstrumental à maneira da economia e da administração estatal.

Com o apoio da interpretação que Schluchter faz da sociologia do direito weberiana, Habermas defende a tese de que o processo de racionalização do direito visto por Weber reflete a mesma seqüência de categorias pré-convencionais, convencionais e pós-convencionais que a psicologia de L. Kohlberg, inspirada em J. Piaget, descobriu para a ontogênese da consciência moral. Segundo Schluchter, que se socorre de Weber, o procedimento legal das sociedades primitivas não conhece um direito objetivo independente das ações, o que, segundo Habermas, corresponde ao estágio pré-convencional do desenvolvimento moral de Kohlberg, no qual o indivíduo age moralmente em função da avaliação que faz das consequiências das suas ações em termos de benefícios e punições. No estágio seguinte, segundo Schluchter, as ações são ajuizadas à luz de normas jurídicas dadas, assentadas sobre princípios metajurídicos segundo os cânones do direito natural, o que corresponde ao estágio convencional de Kohlberg, no qual o indivíduo age moralmente segundo as leis encarnadas 
na figura da autoridade. Finalmente, os princípios sobre os quais assentavam-se as normas jurídicas tornam-se eles proprios reflexivos, passando de metajurídicos a jurídicos. Nesse estágio, que corresponde ao estágio pósconvencional de Kohlberg, no qual o indivíduo age moralmente em função de princípios universais, o direito se torna positivo em sentido estrito.

$\mathrm{O}$ direito moderno resultante desse processo de racionalização distingue-se por três características formais: positividade, legalidade e formalismo. Isto quer dizer que são estabelecidos critérios de validade e criação do direito, estabelecidos critérios de punibilidade e modos de sanção das condutas desviantes de normas pré-estabelecidas e delimitados âmbitos eticamente neutralizados negativamente regulados, isto é, âmbitos onde é permitido tudo que não esteja juridicamente proibido. Essas características explicam, sem dúvida, a adequação do direito moderno aos imperativos funcionais da economia e do Estado modernos, isto é, a institucionalização da ação racional regida por fins. Todavia, essa adequação, por si só, não explica como essas estruturas jurídicas vieram a ser possíveis, o que, segundo Habermas, só se entende a partir das estruturas pósconvencionais de consciência que esse direito encarna. Não fosse assim, o direito moderno não careceria de justificação. Weber atende a esse problema, "mas associa de uma forma tão estreita direito moderno e dominação legal que o princípio de que o direito necessita justificação se desvanece $e$ fica tão somente o princípio da positivização" (Habermas, 1989: 339).

É assim que Weber assimila o direito a um meio de organização que se há de manejar de forma racional regida por fins. Convém, com Habermas, explicitar as três linhas de argumentação em que essa abordagem se manifesta. Em primeiro lugar, na interpretação weberiana do direito natural racional. "Weber vê no direito natural racional o tipo mais puro de validade racional regida por valores e o apresenta como um exemplo impressionante da eficácia externa das relações internas de sentido" (idem: 341). Não obstante, Weber entende que não pode haver um direito natural puramente formalista, uma vez que todo direito natural traz em seu bojo um critério material de legitimidade. Habermas contra-argumenta, afirmando que, ainda que se reconheça as fortes conotações metafísicas do conceito de direito natural, cabe lembrar que "os teóricos do direito natural racional moderno foram os primeiros a responder à exigência de uma fundamentação procedimental do direito, quer dizer, de uma fundamentação a partir de princípios cuja validade pode, por sua parte, ser objeto de crítica (...). Weber confunde novamente as propriedades formais de nível pós-tradicional de fundamentação, com valores particulares, materiais" (idem: 342).

Em segundo lugar, Weber equipara legitimidade e legalidade. Essa solução deriva da problemática que a própria abordagem weberiana co- 
loca de como se pode legitimar uma dominação de tipo legal. A resposta, que implica aquela equiparação, só pode ser: as regras procedimentais para criação, interpretação e aplicação do direito. Habermas, entretanto, observa que "se a legalidade não significa outra coisa que concordância com uma ordem jurídica faticamente vigente, e se essa, como direito estatuído que é, não resulta acessível a uma justificação de tipo prático-moral, então não fica claro de onde extrai a fé na legalidade sua força legitimadora. A fé na legalidade só pode criar legitimidade se supõe já a legitimidade da ordem jurídica que determina o que é legal. Não há maneira de sair desse círculo" (idem: 343 ).

Por fim, Weber defende a tese de que a racionalização material do direito representa uma ameaça para as qualidades formais do direito. Como o processo de racionalização do direito é abordado por Weber do ponto de vista exclusivo da racionalidade regida por fins, as pretensões de validade práticomorais, ironicamente, convertem-se em fonte de irracionalidade ou de debilidade do racionalismo formal do direito. Inexplicavelmente, a tese da perda de liberdade, que encara com ceticismo a autonomização da economia e do Estado frente aos imperativos prático-morais, não é aplicada à esfera do direito. Caso contrário, Weber saudaria, ao invés de criticar, os movimentos antipositivistas que buscam reconectar as esferas jurídica e ética. Contudo, é exatamente o oposto o que ele faz: "a precisão do trabalho jurídico, defende Weber, é rebaixada quando nos considerandos das sentenças se substituem os conceitos jurídicos por arrazoados de tipo sociológico e econômico, ou de tipo ético" (Weber, 1992: 659; apud Habermas, 1989:349-grifo meu -FH).

Todas essas aporias da abordagem weberiana, Habermas pretende superar com sua teoria da ação comunicativa. Num primeiro momento, Habermas propõe, através de uma reconsideração da teoria weberiana da ação, resgatar o conceito mais amplo de racionalidade que Weber emprega na sua teoria da racionalização social, sem restringi-lo ao enfoque unidimensional da racionalidade regida por fins. Num segundo momento, Habermas reavalia as teses da perda de sentido e da perda de liberdade à luz, não da racionalização das orientações de ação, como faz Weber, mas do nível de diferenciação sistêmica, isto é, do grau de desacoplamento radical entre mundo da vida e sistema: nessa perspectiva, perda de sentido e perda de liberdade são vistas como patologias sociais da reprodução simbólica do mundo da vida induzidas sistemicamente. Nesse momento, trataremos somente do primeiro passo.

Como é sabido, Weber define ação como um comportamento humano ao qual o agente associa um sentido subjetivo, seja ele utilitário, valorativo ou afetivo. Assim, o agente pode seguir seus interesses, satisfazer valores ou entregar-se a paixões e desejos. A tipologia oficial da teoria weberiana, que hierarquiza as ações segundo graus decrescentes de ra- 
cionalidade, elege o primeiro caso, racional regido por fins, como referência: o sentido subjetivo compreende, aqui, as conseqüências, os valores, os fins e os meios. Em seguida, temos a ação racional regida por valores, que não submete a controle racional as consequiências. A ação äfetiva, por sua vez, não observa nem conseqüências nem valores. $E$ a tradicional, uma categoria residual, não observa nem mesmo os fins.

Habermas, contudo, propõe uma outra versão da teoria weberiana da ação. "Como Weber parte de um conceito de ação monologicamente estruturado, não pode introduzir o conceito de ação social por via de uma explicação do conceito de sentido". Vê-se assim na necessidade de introduzir novos elementos para explicar a interação social. Com efeito, Weber define "ação social" como aquela que se orienta pela conduta dos outros em seu desenvolvimento e "relação social" como o comportamento de vários agentes que se referem uns aos outros e se orientam por essa reciprocidade. Habermas vê nessas duas últimas definições uma oscilação entre um modelo de ação puramente teleológico e um modelo de ação que contempla formas reflexivas de interação social. No último caso, as ações poderiam distinguir-se pelos mecanismos de coordenação, sejam eles tramas de interesses ou consensos normativos. O proprio Weber teria dado conta dessa distinção ao analisar o processo de transformação de costumes mecanicamente observados em regras convencionais obrigatórias, estabelecidas através de ações comunitárias. Os textos de Weber permitem também estabelecer essa mesma relação, num grau mais alto de racionalidade: teríamos, assim, as ações estratégicas governadas por interesses (como no trafico mercantil moderno) e as ações que repousam em um consenso normativo pós-convencional, atingido através de ações societárias (como no sistema jurídico moderno).

Embora essa leitura encontre pontos de apoio na obra de Weber, particularmente Economia e sociedade, Habermas renuncia à idéia de que esta lhe seria a interpretação mais fiel, uma vez que Weber não distingue com suficiente clareza entre, já no jargão habermasiano, ações orientadas ao êxito (mediadas por tramas de interesses) e ações orientadas ao entendimento (mediadas por acordo normativo). Não obstante, Habermas encontra nessa tipologia alternativa a forma de recuperar o conceito amplo de racionalidade implícito no processo de racionalização ética que Weber estuda no plano das tradições culturais.

\section{WEBER, ECONOMISTA MARGINALISTA}

Para os propósitos de Habermas, sua interpretação da obra de Max Weber não poderia ser mais brilhante. Por meio do exame da teoria 
da ação e do diagnóstico da modernidade weberianos, Habermas abre caminho para elucidar as aporias dessas teses nos seus próprios termos (ação comunicativa e mundo da vida). Entretanto, gostaria de tecer as seguintes considerações sobre a leitura que Habermas faz de Weber.

Em primeiro lugar, Habermas negligencia o que certamente foi uma das maiores influências no pensamento de Weber: a revolução marginalista. A teoria do valor-utilidade, desenvolvida simultaneamente, na década de 70 do século passado, por Menger, Jevons e Walras, e posteriormente abraçada, com entusiasmo, por Marshall, Pareto e pelos austríacos, notadamente Böhm-Bawerk, sem dúvida impactou de uma maneira evidente a teoria weberiana da racionalização. $E$ isso não podia ser diferente. O maior "problema" de Weber atendia pelo nome de Karl Marx. Não se consegue percorrer muitas páginas das duas maiores obras de Weber, Economia e sociedade e Ensaios sobre sociologia da religião, sem esbarrar em referências, implícitas ou explícitas, ao materialismo histórico. Obviamente, não poderia passar despercebido de Weber um dos ataques mais frutíferos ao marxismo, ataque esse promovido, ademais, no campo de batalha do proprio inimigo: a economia. Não custa lembrar que Weber era considerado por muitos, inclusive por ele próprio, além de sociólogo, economista. Se especularmos sobre a posição que a economia ocupa na abordagem weberiana chegaremos a alguns resultados interessantes, dentre os quais, a reavaliação da influência de Nietzsche sobre Weber, que, como se verá, não o vê apenas como crítico da cultura, como quer Habermas, mas como fonte de inspiração de uma nova "ontologia social". $\mathrm{Na}$ leitura de Habermas, Nietzsche, a grande alternativa a Marx no campo da filosofia, tem um papel subestimado na formação do pensamento de Weber. $\mathrm{O}$ que se segue tem a pretensão de demonstrar, justamente, que o marginalismo e o nietzchianismo são os dois grandes pilares que sustentam a crítica weberiana ao materialismo histórico. Na verdade, essa tese simplesmente radicaliza os argumentos expostos por Gabriel Cohn, no seu brilhante estudo sobre os fundamentos da sociologia weberiana, intitulado Crítica e resignação, onde o autor não só valoriza corretamente a influência de Nietzsche sobre Weber, como também já faz notar a influência de Menger sobre Weber, pelo menos no que diz respeito à controvérsia metodologica.

Numa das passagens, no meu entender, mais interessantes de Economia e sociedade, Weber descreve o que poderia ser denominado como sendo sua "dialética da religião". Diz o texto: "o progresso das idéias sobre o poder de um deus e de seu caráter como senhor pessoal condiciona, então, o predomínio crescente dos motivos não mágicos. Deus se converte em um grande senhor (...) ao qual há que se aproximar, não com 
regras mágicas coercitivas, mas com súplicas e dons. Porém, tudo o que estes motivos trazem de novo com respeito à magia são também prosaicos elementos racionais como os da mesma magia. O traço fundamental é o do ut des [dou para que dês- FH]. Este caráter se adere à religiosidade cotidiana das massas de todos os tempos e povos e também a todas as religiões. O conteúdo de toda 'pregação' normal é o alijamento de todo mal exterior neste mundo e o procurar-se vantagens terrenas, inclusive nas religiões mais ultramundanas. Todo traço que vá mais além disso é obra de um processo específico com dupla peculiaridade. De um lado, uma sistematização racional, cada vez mais ampla, do conceito de Deus e igualmente do pensamento sobre as possíveis relações do homem com o divino. Porém, por outro, quanto ao resultado, um retrocesso característico daquele racionalismo originariamente prático. Pois o 'sentido' da conduta especificamente religiosa se busca, cada vez menos, paralelamente com aquela racionalização do pensar, em vantagens puramente externas da vida econômica cotidiana; desse modo, $o$ fim da conduta religiosa se 'irracionaliza' até o ponto em que, por fim, estes fins 'não mundanos', quer dizer, não econômicos, valem como o específico da conduta religiosa. Mas por isso mesmo, constitui um dos pressupostos desse desenvolvimento 'extraeconômicos', a existência de portadores pessoais desta idéia" (Weber, 1992: 344/5).

Nessa passagem Weber ocupa-se exclusivamente com a gênese das religiões. $\mathrm{O}$ racionalismo prático da conduta mágica, baseado num "toma-lá-dá-cá" com a natureza, dá lugar a um processo de racionalização do pensar concomitante com a irracionalização dos fins perseguidos. Sabemos que a dialética weberiana da religião não pára aí, uma vez que a ética protestante, como vimos, recupera de outra forma a racionalização prática, através da metodização da vida intramundana, mas conduzindo a um quadro no qual a apropriação de riqueza aparece como um fim em si mesmo, descolado da lógica da satisfação das necessidades materiais dos indivíduos. Aqui também o movimento de racionalização reveste-se de uma aparente irracionalidade. Assim o entendeu Brentano. Weber, entretanto, alerta que o conceito de racional é só à primeira vista unívoco, pois que para o irreligioso a conduta religiosa é irracional do mesmo modo que para o hedonista o é a conduta ascética (cfr. Weber, 1984: 42n.).

O que nos interessa no texto citado, porém, são as condições de passagem da magia à religião. $O$ texto diz que essa passagem é obra de um processo, mas não diz o que o determina. Uma das suas condições, entretanto, é encontrada seguindo o texto umas setenta páginas: "a idéia de um além", ensina Weber, "se acha em germe no desenvolvimento da magia na direção de uma crença nas almas. Mas nem sempre a existência de almas 
se condensa em um reino especial dos mortos. (...). Uma certa preocupação pelo próprio destino depois da morte surge, de acordo com a 'lei da utilidade marginal', quando estão cobertas as necessidades mais urgentes desta vida e, portanto, se limita, em primeiro lugar, ao círculo dos nobres e proprietários. Só eles, às vezes só os chefes e sacerdotes, não os pobres, raramente as mulheres, podem assegurar-se da existência no além..." (Weber, 1992: 413). “(...) A necessidade de salvação e a religiosidade ética tem outra fonte que a situação dos negativamente privilegiados [qual seja...]: o puro intelectualismo, especialmente as necessidades metafísicas do espírito, que não é levado a meditar sobre questões éticas e religiosas por nenhuma penúria material, senão por uma força interior que o empurra a compreender o mundo como um cosmos com sentido, e a tomar posição frente a ele" (idem, 399).

A teoria da utilidade marginal sugere a Weber que há uma certa hierarquia entre interesses materiais e interesses ideais ou metafísicos. Os homens só perseguem os bens soteriológicos depois de terem garantido os bens terrenos de que necessitam para sobreviver nesta vida. Daí que a passagem da magia para a religião caminha com um certa divisão do trabalho entre os sexos, com uma distribuição desigual de bens terrenos, ou se quisermos dizer provocativamente, com a emergência, no plano individual, de um reino da liberdade para além do reino da necessidade. Digo "reino da liberdade" porque para Weber a satisfação das necessidades metafísicas se dá num processo que responde a uma lógica própria, diferente da lógica do processo de satisfação das necessidades materiais.

Weber, aparentemente, contempla o fato de a satisfação de necessidades metafísicas se dar no plano exclusivamente individual e, nesse caso, não ter relevância social: compreender o mundo como um cosmos com sentido e tomar posição frente a ele pode não envolver uma tomada de posição ativa frente aos outros. Assim, por exemplo, Weber constata que o budismo se converteu em uma das maiores religiões missionárias da Terra, mas surpreende-se com esse fato por não descobrir, do ponto de vista da sua dogmática, motivo racional que o levasse a isso. Weber contorna o problema com a hipótese de que Buda, afinal, decidiu predicar a salvação dos homens por considerar a possibilidade da existência de pessoas com qualificação ambígua, para a santidade ou para a perdição, que poderiam ser influenciados positivamente (cfr. Weber, 1987: 242). Mas isso poderia não ter sido assim.

É claro que, como sociólogo, Weber só se interesse por aquelas situações em que a busca de sentido cósmico por aqueles indivíduos dotados de carisma engendra, por inspiração ou endopatia, as religiões universais. É nesse contexto que Weber postula uma esfera de liberdade humana, 
ou seja, a possibilidade do homem agir segundo "valores" que dêem um sentido não material a suas ações. Quanto a isso, observe-se que, sem a distinção entre interesses materiais e interesses ideais, a distinção entre interesses (materiais e ideais) e valores (ou idéias) se veria limitada à esfera cognitivo-instrumental. Nessa hipótese, as únicas inovações práticas possíveis seriam as inovações técnicas e os personagens mais relevantes da história seriam os empreendedores. Uma tal leitura parcial de Weber é possível e foi ela que permitiu a Schumpeter, em Capitalismo, socialismo e democracia, reavaliar as previsões econômicas de Marx: enquanto Weber se preocupa com o desaparecimento dos profetas, Schumpeter se preocupa com o desaparecimento dos entrepreneurs, embora ambos apontem na mesma direção da burocratização, que sufoca o espírito (ético, para o primeiro, econômico, para o segundo) do capitalismo. Contudo, só a hipótese de interesses ideais para além de interesses materiais permite a Weber conceber a inovação também no plano ético-religioso, o que para sua sociologia é um passo absolutamente imprescindível.

A partir daí, temos duas conseqüências. Em primeiro lugar, Weber rompe com um materialismo ingênuo que propugna um condicionamento unilateral entre base e superestrutura e fala, então, de um "condicionamento recíproco" de fatores econômicos e culturais. Id́́ias e interesses são tomados como igualmente originários de modo que o processo de modernização permite uma leitura "a partir de cima", ou seja, a partir das estruturas de consciência, e outra "a partir de baixo", ou seja, a partir de conflitos econômicos e políticos. Em segundo lugar, Weber abre espaço à influência da genealogia da moral de Nietzsche: nesse ponto, a relação entre Weber e a filosofia neokantiana do valor, não raramente, é superestimada. Como observa E. Fleischmann: "Para o próprio Kant não havia mais que um só 'valor', a dignidade do homem livre - o único existente que é sempre 'fim', jamais 'meio' - que, por suas ações racionais, cria-se a si proprio das normas, idéia retomada por Fichte e os filosofos românticos que fizeram do 'eu' humano a fonte inesgotável de valores e de normas. Os 'valores' (no plural), enquanto normas pré-existentes da ação humana, apareceram pela primeira vez na Lógica de Lotze, e depois no seu discípulo e sucessor Wildelband. Um contemporâneo de Wildelband, Nietzsche, retomou igualmente o problema dos valores, mas, longe de os considerar como entidades culturais normativas e pré-existentes, ele insistiu no seu caráter relativo, arbitrário, e mesmo falso: eles não seriam para ele mais do que 'ideologias' que revelam sobretudo a vontade cristã de dominar as almas e os corpos. Weber, que jamais desconsiderou o caráter subjetivo, 'demasiado humano' dos valores, se coloca visivelmente ao lado de Nietzsche" (Fleischmann, 1964: 198). 
A interpretação de Fleischmann é precisa, mas como ele não dá conta da influência do marginalismo sobre Weber, acaba por não perceber exatamente como Nietzsche é por ele absorvido. A ontologia nietzschiana, sem dúvida, faz-se presente no pensamento de Weber: o homem para ele é igualmente um criador de valores. Mas, contrariamente a Nietzsche, Weber associa a figura do criador de valores inclusive aos fundadores carismáticos das religiões universais. E nos dá um exemplo concreto da limitação da abordagem de Nietzsche: "Em nenhuma parte, diz Weber, vêemse mais claramente os limites da importância que corresponde o 'ressentimento' e a aplicação demasiado universal do esquema da 'repressão', que no erro de Nietzsche [grifo meu - FH] ao aplicar seu esquema ao caso, totalmente inadequado, do budismo. É o budismo o mais radicalmente contrário a todo moralismo ressentido; trata-se, preferivelmente, de uma doutrina de salvação orgulhosa e aristocrática (...)" (Weber, 1992: 399). De fato, os estudos sobre sociologia da religião de Weber limitam o esquema de Nietzsche ao caso específico do judaísmo (cfr. Weber, 1988). Os profetas carismáticos, aristocráticos em sua maioria, são, para Weber, fundadores de novas ordens e novos valores, valores esses que têm um impacto fundamental nas outras esferas da vida, particularmente a econômica. Em Weber, há mesmo uma ruptura entre religião e moral de rebanho. Segundo ele, aliás, as massas, deixadas à própria sorte, dificilmente romperiam com o pensamento mágico, pautado pelo racionalismo prático. Isso não exclui, todavia, o movimento a partir do qual a doutrina religiosa é modificada pela hierocracia para atender aos anseios materiais dessa mesma massa, não raramente para domesticá-la.

Mas, para aqueles que acham que a minha argumentação, até aqui, não oferece provas conclusivas para atestar a importância da influência do marginalismo sobre Weber, ofereço ainda um outro exemplo. Weber refere-se à teoria da utilidade marginal num momento decisivo do desenvolvimento da sua teoria da ação. "Atua racionalmente regido por fins, diz ele, quem oriente sua ação pelo fim, meios e conseqüências implicadas nela e para o qual sopese racionalmente os meios com os fins, os fins com as consequiências implicadas e os diferentes fins possíveis entre si. (...). Por sua parte, a decisão entre os distintos fins e conseqüências concorrentes e em conflito pode ser racional regida por valores, em cujo caso a ação é racional regida por fins só nos meios". A dificuldade teórica que aparece nesse ponto é a de saber por que outro critério que não o valorativo o agente opta por fins e conseqüências concorrentes. Pois, com exceção da situação em que o valor que move a ação se eleve à significação de absoluto, a ação racional regida por valores considera também as consequiências concorrentes. A continuação do texto citado esclarece: "Ou 
bem $\mathrm{o}$ ator, sem orientação racional alguma por valores em forma de 'mandatos' ou 'exigências', pode aceitar esses fins concorrentes e em conflito em sua qualidade de desejos subjetivos [atente o leitor para a introdução do outro critério -FH] em uma escala de urgências conseqüentemente estabelecida, orientando por ela sua ação, de tal maneira que, tanto quanto possivel, sejam satisfeitos na ordem dessa escala, segundo o princípio da utilidade marginal" (Weber, 1992: 21). Ainda que Weber reconheça que a concepção de uma racionalidade absoluta no caso de uma ação racional regida por fins é uma construção hipotética, o fato é que, se por trás da escolha do fim sempre se encontrasse um valor, o próprio diagnóstico weberiano da modernidade estaria comprometido. Weber não admite uma tal solução, tanto que recusa a visão utilitarista, que, como já foi dito, converte os interesses em princípios éticos e hipostasia a racionalidade regida por fins, convertendo-a em uma valor. E a distinção entre fins e valores Weber não pode estabelecer sem um outro critério, isento de valor, na escolha dos fins. O marginalismo lhe oferece mais uma vez a saída: uma escala de preferências subjetivas.

Neste momento, vale a pena introduzir minha segunda objeção à leitura habermasiana de Weber. Façamos uma especulação sobre o porquê da visível preferência de Weber pelas normas jurídicas de caráter formal às de caráter material, no direito, e pela racionalidade formal à material, na gestão econômica e na política. Sabemos que com a dissolução das imagens religiosas-metafísicas do mundo tem-se a impossibilidade de conceber o mundo como um cosmos com (um) sentido. Recai-se num politeísmo, desta vez, desencantado, que implica a irreconciabilidade das esferas do bom, do belo e do verdadeiro. Até aqui, nada de novo. Porém, o que a leitura de Habermas não contempla, mas estou convencido que os textos de Weber sugerem é que, pelo menos na esfera prático-moral, há uma espécie de politeísmo de segunda ordem, isto é, tudo se passa como se por dentro dessa esfera cultural de valor, forças, próprias dela, se degladiassem sem descanso. Poder-se-ia até pensar em extrapolar o argumento para as outras duas esferas, enfocando a esfera cognitiva a partir de diferentes paradigmas científicos concorrentes e a esfera expressiva a partir de diferentes perspectivas estéticas, mas Weber, nesse particular, só é sugestivo em relação à esfera prático-moral: nessa última, segundo minha leitura de Weber, parecem concorrer, num embate sem fim, diferentes visões de mundo como hedonismo, utilitarismo, igualitarismo, etc. E se isso é assim, sobrecarregar os âmbitos institucionais de racionalidade regida por fins com pretensões valorativas significa tão somente transportar para dentro do direito, da empresa capitalista e do Estado moderno, o politeísmo ético do qual eles devem ficar isentos, pois comn ñ̃n se pode de- 
cidir de maneira racional entre valores, mas tão somente entre fins e conseqüências, a racionalidade material, no direito, na economia e no Estado, sem trazer vantagem alguma, perde em inequivocidade para a racionalidade formal. Nesse contexto, resta a Weber se perguntar pela única ética possível. A resposta só pode ser: uma ética desprovida de valor. Não vejo outra forma de encarar a ética da responsabilidade!

Agora talvez fique mais aparente a conexão entre a tese da perda de sentido e a tese da perda de liberdade e a relação delas com o marxismo. Com Löwith podemos dizer: "a força motiva da abordagem de Weber ... era a contradição, sempre reposta, entre o reconhecimento de um mundo racionalizado e a contra-tendência na direção da liberdade de autoresponsabilidade. (...) Marx queria achar um jeito de abolir a existência humana específica (...) característica do mundo racionalizado (...). Weber pergunta-se, preferencialmente, como o homem como tal, dentro de sua existência humana inevitavelmente 'fragmentada', poderia, não obstante, preservar a liberdade de auto-responsabilidade do indivíduo (...). Esta diferença nas suas visões de mundo e em suas idéias de humanidade está expressa na dissimilaridade de suas perpectivas determinantes para a interpretação do moderno mundo capitalista-burguês. Para Weber: 'racionalidade'. Para Marx: 'alienação"' (Löwith, 1993: 77ss).

Antes de concluir, uma última questão merece elucidação. Ainda que minha versão da teoria weberiana possa lhe dar uma maior coerência, restaria a Habermas a crítica de que com a diferenciação de uma esfera prático-moral especializada, poder-se-ia esperar que a racionalização ética prosseguisse dentro desta esfera, atendo-se daí em diante à legalidade própria de uma razão prática emancipada. Além disso, apesar da perda de unidade substancial da razão, fruto dessa mesma diferenciação de esferas culturais de valor, não se poderia negar que essa unidade pode ser recuperada no plano formal a partir do desempenho argumentativo comum a elas. A crítica é absolutamente procedente, mas faço a ressalva de que quando Habermas formula sua magnífica "ética do discurso" incorre numa visível confusão entre o lógico e o histórico. Explico-me. Dentre as críticas que Habermas faz a Weber, uma delas, ainda não mencionada, reza que os estudos de Weber sobre a ética protestante "não tratam de relações causais, senão de uma 'relação de afinidade' entre a ética protestante e o espírito do capitalismo, condensado na cultura profissional moderna. Portanto, tão pouco satisfazem o proprio desiderato de Weber de uma análise 'da forma em que a ascese protestante foi, por sua vez, influída no seu nascimento e configuração pela totalidade das condições socioculturais, em especial, pelas econômicas (...)" (Habermas, 1989: 293; o trecho entre aspas nesta citação é de Weber, 1984: 201). Ora, pode-se dizer que essa crítica aplica- 
se, ipsis litteris, à abordagem de Habermas. Nem a diferenciação de esferas culturais de valor nem a institucionalização da ação racional regida por fins implicam ou exigem, per se, a emergência da ética do discurso: entre a diferenciação das esferas de valor e a ética do discurso há uma mera possibilidade lógica; e entre os subsistemas (Estado moderno e grande indústria capitalista) e a ética do discurso há um non sequitur. Falta à fundamentação da ética do discurso de Habermas a discussão dos seus "pressupostos" histórico-materiais.

Mas se as coisas são assim, é interessante observar que a crítica de Habermas a Hegel, Schelling e Schlegel que buscaram, respectivamente, na razão ou numa nova mitologia (filosoficamente fundamentada ou transformada em esperança messiânica), algo que poderia substituir o poder unificador da religião mostra-se, dessa perspectiva, francamente insatisfatória. Se Weber, um século mais tarde, ainda não podia enxergar uma saída comunicacional, a la Habermas, para o problema, pois que esta saída, então, apenas se esboçava historicamente, muito menos os três filósofos citados. A evolução que vai do jovem Hegel (que ainda não abre mão da religião como poder unificador pois que ela valida, pelo entusiasmo popular que gera, os direitos que a razão outorga), passando pelo Hegel maduro (que, ao constatar o destino que tanto a religião quanto a arte experimentam na modernidade, encara a subjetividade de alto grau do Estado como a garantia da esfera da eticidade), passando pela crítica radical da razão de Nietzsche (que vai encarar o Estado como perversão da vontade de potência), até o alargamento do conceito de razão por Habermas (que vai reduzir o Estado a um mero subsistema, reencontrando a esfera da eticidade em um mundo da vida simbolicamente reproduzido pelo agir orientado ao entendimento), essa evolução, eu não a considero uma evolução conceitual, mas uma evolução histórico-prática. A ética do discurso, verdadeiramente, s $\sigma$ se estabiliza no século $\mathrm{XX}$, particularmente no pósGuerra. Uma sociedade só pode abrir mão definitivamente das suas convenções, submetendo-as a um teste reflexivo, quando a maioria hegemônica dos indivíduos que a compõem esteja apta a reger suas ações por princípios. Essa evolução é tanto cultural quanto material. Tanto que hoje, infelizmente, os pressupostos materiais da ética do discurso estão de tal modo ameaçados que é difícil dizer se a sociedade moderna continuará podendo garantir sua coesão a partir da mesma dinâmica dos anos dourados do capitalismo.

FERNANDO HADDAD é mestre em Economia e doutor em Filosofia pela USP. 


\section{REFERÊNCIAS BIBLIOGRÁFICAS}

COHN, G., Crítica e resignação, T.A.Queiroz, São Paulo, 1979.

FLEISCHMANN, E., "De Weber à Nietzsche", in Archives Européennes de Sociologie, Tomo V, número 2, 1964.

HABERMAS, J., Consciência moral e agir comunicativo, Tempo Brasileiro, Rio de Janeiro, $1989 \mathrm{~b}$.

,Teoría de la Acción Comunicativa, Vol. I, Taurus, Buenos Aires, 1989.

, Teoría de la Acción Comunicativa, Vol II, Taurus, Buenos Aires, 1990a.

O discurso filosófico da modernidade, Publicações Dom Quixote, Lisboa, $1990 \mathrm{~b}$.

LÖWITH, K., Max Weber and Karl Marx, B. S. Turner, London, 1993.

NIETZSCHE, F., "Obras escolhidas", in Nietzsche, Vol. I e II, Nova Cultural, São Paulo, 1987.

SCHUMPETER, J.A., A teoria do desenvolvimento econômico, Abril Cultural, São Paulo, 1982.

Capitalismo, socialismo e democracia, Zahar, Rio de Janeiro, 1984.

WEBER, M., Ensayos sobre Sociologia de la Religión, Vol. I, Taurus, Madrid, 1984. , Ensayos sobre Sociologia de la Religión, Vol. II, Taurus, Madrid, 1987. , Ensayos sobre Sociologia de la Religión, Vol. III, Taurus, Madrid, 1988. - Economia y Sociedad, Fondo de Cultura Económica, México, 1992. , Ciência e política: duas vocações, Cultrix, São Paulo, 1993. 